\title{
CORRIGENDUM
}

\section{Intake and dietary sources of haem and non-haem iron among European adolescents and their association with iron status and different lifestyle and socio-economic factors}

S Vandevijvere, N Michels, S Verstraete, M Ferrari, C Leclercq, M Cuenca-García, E Grammatikaki, Y Manios, F Gottrand, J Valtueña, M Kersting, M Gonzalez-Gross, L Moreno, T Mouratidou, K Stevens, A Meirhaeghe, J Dallongeville, M Sjöström, L Hallstrom, A Kafatos, K Widhalm, D Molnar, S De Henauw and I Huybrechts on behalf of the HELENA study group

European Journal of Clinical Nutrition (2013) 67, 1227; doi:10.1038/ejcn.2013.189

Correction to: European Journal of Clinical Nutrition (2013) 67,

The authors apologize for any inconvenience caused. 765-772; doi: 10.1038/ejcn.2013.100; published online 22 May 2013

Since the publication of this paper, the author JV Santamaría's name has been changed to J Valtueña as above. 